Ks. JAN ZWIAZZEK

\title{
DZIEJE INSTYTUCJI DIECEZJALNYCH W CZĘSTOCHOWIE
} (c.d.)

\author{
4. POWSTANIE DEKANATU CZESTOCHOWSKIEGO \\ I JEGO DZIEJE W OKRESIE NIEWOLI NARODOWEJ
}

Dotychczasowa parafia częstochowska należała do rozległego dekanatu lelowskiego w diecezji krakowskiej. Liczących pod koniec XVIII wieku wiele parafii dekanat ze względu na bardzo rozległe terytorium sprawiał wiele trudności dziekanowi $w$ jego administrowaniu. Dziekan nic mógł przeprowadzać wizytacji kanonicznych we właściwym czasie, bowiem jednocześnie pełnił także obowiazki proboszczowskie. Nie mógł także we właściwy sposób czuwać nad działalnością i sposobem życia kleru dekanalnego. Duże trudności występowały także przy wprowadzeniu $\mathrm{w}$ dekanacie rozporządzeń władzy diecezjalnej $\mathrm{w}$ sprawie duszpasterstwa wiernych. Wreszcie dziekan nie mógł należycie troszczyć się o stan materialny światyń i zabudowań kościelnych na terenie swego dekanatu. W diecezji krakowskiej już dawno istniały plany przeprowadzenia reorganizacji sieci dekanalnej. Główną przyczyna tych projektów były trudności w działalności dziekanatów w rozległych dekanatach. Terytorium dekanatu lelowskiego należało do największych w diecezji. W programie zmian granic dekanatów, dekanat lelowski był także brany pod uwagę. Było to bardzo uzasadnione dążenie, ponieważ w zachodniej czesści dekanatu powstało i rozwijało się miasto Częstochowa, a okoliczności wskazywały, że to miasto będzie się nadal rozwijać. Było to największe miasto w tej części diecezji krakowskiej, będące jednocześnie centralnym ośrodkiem dla okolicznych miast i wsi. Taką rolę dla miasta wyznaczało jednocześnie sanktuarium jasnogórskie, do którego przybywali wierni z całej okolicy. Jeszcze przed II rozbiorem Polski istniał plan utworzenia dekanatu częstochowskiego. Władza diecezjalna w Krakowie była przynaglana przez władze austriackie do przeprowadzenia reorganizacji sieci parafialnej i dekanalnej w części diecezji, będącej pod władzą austriacka. Był to bowiem czas, kiedy na ziemiach austriackich były wprowadzane reformy józefińskie. Biskup krakowski Feliks Paweł Turski przeprowadzał zmiany w ustroju administracyjnym diecezji nie tylko na ziemiach znajdujących sie pod austriacką dominacją, ale analogiczne zmiany wprowadzał także na ziemiach leżących poza zaborem austriackim. Dotyczyło to także okolic Częstochowy. Według biskupa Turskiego, nowy podział diecezji na dekanaty miał przyczynić się do udo- 
skonalenia pracy duszpasterskiej, a szczególnie miał ułatwić pracę dziekanom w nadzorowaniu życia religijnego wieñinch oraz życia i działalności duchowieństwa tak świeckiego jak i zakonnego. W mniejszych dekanatach dziekani mogli dokładniej wypełniać swoje obowiązki ${ }^{1}$.

W takich warunkach na mocy zarządzenia biskupa Feliksa Pawła Turskiego został przeprowadzony podział dotychczasowego dekanatu lelowskiego. Tu trzeba zaznaczyć, że znaczenie Lelowa jako ośrodka dekanalnego a także powiatowego znacznie się zmniejszyło, nie było odpowiednich warunków do przeprowadzenia większych zjazdów kościelnych i państwowych. Tymczasem w zachodniej części dekanatu powstały nowe ośrodki miejskie - Częstochowa, Kłobuck i Żarki. Ówczesny dziekan dekanatu lelowskiego ks. Józef Rudzki (Rucki), proboszcz parafii Kromołów i Skarżyce, zwołał duchowieństwo dotychczasowego dekanatu lelowskiego w dniu 22 listopada 1791 r. Kongregacja duchowieństwa odbyła się w kościele pod wezwaniem śś. Apostołów Szymona i Judy Tadeusza w Żarkach. Podczas trwania tej kongregacji dziekan ogłosił decyzję biskupa F. P. Turskiego, stwierdzającą podział rozległego dekanatu lelowskiego na 4 dekanaty - lelowski w nowych granicach, częstochowski, przyrowski i szczekociński. Dwa ośrodki dekanalne - Przyrów i Szczekocin - były jednak zbyt małe i leżały z dala od innych parafii, dlatego wkrótce zostały ponownie zreformowane. Biskup Turski wydał bowiem zarządzenie, iż ośrodki dekanalne powinny znajdować się w większych miastach. $Z$ tego powodu został zlikwidowany dekanat przyrowski, a część dekanatu wraz z Przyrowem została przyłączona do dekanatu częstochowskiego (także parafia Żuraw), a pozostała część dekanatu przyrowskiego została włączona do nowego dekanatu pilickiego. W tym czasie do dekanatu częstochowskiego należały następujące parafie: Biała, Częstochowa, Kłobuck, Krzepice, Miedzno, Poczesna, Przyrów, Przystajń, Truskolasy, Wilkowiecko i Żuraw².

Wkrótce jednak na tym terenie nastapiły ważne zmiany w administracji państwowej i kościelnej. Już po drugim rozbiorze okolice Częstochowy, Siewierza i Pilicy znalazły się pod dominacją pruską. W zakresie przynależności kościelnej zmiany nastapiły dopiero po III rozbiorze Polski. Władze pruskie po przyłączeniu do Prus Nowego Śląska i okolic Częstochowy podjęły intensywne starania o właczenie tych terenów pod administrację kościelną tych ośrodków diecezjalnych, które były w zaborze pruskim. Jednocześnie oznaczało to, iż te same władze dążyły do wyłączenia tych ziem spod jurysdykcji biskupa krakowskiego. W początkowej fazie realizacji tych projektów władze pruskie jeszcze nie ośmielały się poddać Nowego Śląska pod administrację biskupa wrocławskiego, ale sugerowały ich przyłączenie do archidiecezji gnieźnieńskiej, bowiem archidiecezja wraz z Gnieznem znalazła się w zaborze pruskim, a dekanat częstochowskim leżał przy dawnej granicy pomiędzy diecezją krakowską a archidiecezją gnieźnieńską. Jednakże bar-

${ }^{1}$ P. N a t a n e k, Organizacja terytorialna diecezji krakowskiej w latach 1795-1939, Kraków 1995, ss. 23-24, 29.

${ }^{2}$ B. K u m o r, Brewe papieskie właczajace Nowy Slask do diecezji wroctawskiej. „Archiwa, Biblioteki i Muzea Kościelna" t. 16:1968, s. 311-314; J. W i š n i e w s k i, Diecezja częstochowska. Opis historyczny kościołów i zabytków w dekanatach: będzińskim, dąbrowskim, sqczewskim, zawierckim i żareckim oraz parafii Olsztyn, Mariówka i Opocz, 1936, s. 528-529. 
dzo szybko te zamiary zostały zaniechane, a władze pruskie zdecydowały się na realizacje projektu bezpośredniego włączenia przygranicznych terenów z diecezji krakowskiej do diecezji wrocławskiej. Biskup wrocławski Józef Chrystian Hohenlohe-Waldenburg-Bertenstein zdecydowanie takie plany popierał. Najpierw władze pruskie nie zezwoliły biskupowi krakowskiemu na wypełnianie obowiazków pasterskich w tej części diecezji krakowskiej, która znalazła się pod okupacją pruska. W takich okolicznościach biskup wrocławski utworzył w dniu 11 IV 1799 r. na tym terenie komisariat siewierski, będacy pod jego administracją. Nieznana dotychczas na tym terenie jednostka administracji kościelnej obejmowała dekanaty - częstochowski, pilicki i siewierski. Pod jurysdykcją biskupa wrocławskiego została zmieniona dawna nazwa dekanatów na archiprezbiteraty, co było charakterystyczne dla administracji kościelnej na ziemiach niemieckich. Jednakże nawet takie rozwiazanie przez biskupa wrocławskiego spraw zwiazanych $\mathrm{z}$ administracją kościelną na zaanektowanym terenie nie usatysfakcjonowało władz pruskich. Jeszcze w tym samym roku władze berlińskie zwróciły się bezpośrednio do Stolicy Apostolskiej z postulatem zmiany granic diecezji wrocławskiej i przesunięcia ich w kierunku wschodnim czyli chodziło im o włączenie do diecezji wrocławskiej wymienionych 3 dekanatów z diecezji krakowskiej. W wyniku tych nacisków papież Pius VII na mocy brewe „Ad universam Dominici gregis” $z$ dnia 9 kwietnia $1800 \mathrm{r}$. dokonał inkorporacji komisariatu siewierskiego do diecezji wrocławskiej. Decyzja papieska posiadała charakter stały, a w przyszłości mogły je zmienić także wyłącznie decyzje papieskie. Wykonawcą tego dokumentu papież mianował biskupa poznańskiego Ignacego Raczyńskiego. Władze pruskie wydały odpowiednie placetum regium w dniu 20 czerwca $1800 \mathrm{r}$. wyrażając zgodę na wykonanie pisma papieskiego. Zgodę musiał wyrazić także biskup krakowski Józef Olechowski, co w zaistniałych okolicznościach było jedynie formalnością. Żądane pismo biskup krakowski wystawił w dniu 3 II 1801 r. Odtąd dekanat częstochowski należał do diecezji wrocławskiej ${ }^{3}$.

Oficjalnie aktu inkorporacji komisariatu wrocławskiego do diecezji wrocławskiej dokonał biskup Ignacy Raczyński, który przybył do Żarek wraz z kanonikiem ks. dr. Mateuszem Zymchanowskim. W dniu 5 maja 1801 r. biskup Raczyński ogłosił decyzje papieskie zebranemu duchowieństwu z całego komisariatu. Biskupa wrocławskiego reprezentował jako jego delegat, wcześniej mianowany na stanowisko komisarza siewierskiego ks. dr Marcin Siemieński, kanonik kielecki i proboszcz w pobliskiej parafii Koziegłówki (Veterae Koziegłowy). Zgromadzonych ok. 70 duchownych w kościele parafialnym w Żarkach złożyło przysięgę wierności biskupowi wrocławskiemu ${ }^{4}$. Charakterystycznym było to, że władze pruskie centrum komisariatu utworzyły w Siewierzu, a nie w znacznie większej i sławniejszej Częstochowie. Okupacyjne władze zapewne nie chciały tworzyć centralnego ośrodka kościelnego dla rozległego terenu z powodu sławy Częstochowy jako polskiego miasta ze znanym sanktuarium Matki Boskiej.

W archiprezbiteracie częstochowskim (podobnie jak w dawniejszym dekancie z 1791 r.) znalazły się następujące parafie: Biała, Częstochowa, Miedzno,

${ }^{3}$ B. K u m o r, Breve papieskie..., s. 311-314.

${ }^{4}$ J. W i śn i e w s k i, Diecezja częstochowska..., s. 530. 
Poczesna, Przyrów, Przystajń, Kłobuck, Krzepice, Truskolasy, Wielkowiecko i Żürāw. Bỳiy to rozlegle parañe, zwłaszcza Częstochowa i Kłobuck. W granicach archiprezbiterium częstochowskiego były następujące klasztory: 3 klasztory paulińskie - na Jasnej Górze, przy kościele św. Zygmunta i przy kościele św. Barbary, a także klasztor Bernardynów w Przyrowie i klasztor Kanoników Regularnych w Kłobucku. Dziekanem był ks. Filip Raczkowski, proboszcz parafii Przyrów, najprawdopodobniej dlatego, że Paulini nie pełnili tego rodzaju urzędów diecezjalnych. W okresie Księstwa Warszawskiego i w początkowych latach Królestwa Polskiego proboszcz częstochowski o. Hilarion Szuffranowicz zorganizował w parafiii częstochowskiej szkoły elementarne. Natomiast w całym dekanacie częstochowskim nadzór nad organizowaniem i działalnością szkół elementarnych sprawował dziekan ks. Michał Zagalski, proboszcz w Białej. Dzięki jego wysiłkom na terenie dekanatu zostało zorganizowanych 36 szkół elementarnych ${ }^{3}$.

W administracji kościelnej zmiany nastapily już za czasów Księstwa Warszawskiego. Biskup wrocławski musiał się zrzec jurysdykcji nad zagarniętymi dekanatami i przekazać władzę kościelną biskupowi krakowskiemu. $\mathrm{Na}$ stałe uregulowanie problemu przynależności diecezjalnej należało jeszcze czekać. W czasach Królestwa Polskiego władze rosyjskie wymusiły na pap. Piusie VIII przeprowadzenie nowego podziału na tych ziemiach na metropolie i diecezje. Intencją władz rosyjskich było zacieranie dawnych polskich podziałów terytorialnych. Bulla pap. Piusa VII „Ex imposita nobis" z dnia 30 czerwca 1818 r. wprowadziła nowy podział kościelny na ziemiach Królestwa Polskiego. Tereny w okolicach Częstochowy, które dawniej należały do diecezji krakowskiej (w zaborze pruskim do diecezji wrocławskiej) teraz zostały włączone do diecezji kaliskiej czy włocławskiej. Zostały jednocześnie zerwane więzy metropolitalne z Gnieznem, a nowa diecezja została włączona do metropolii warszawskiej.

Pod presja władz carskich został przeprowadzony nowy podział na dekanaty, który także zawierał dawne podziały na dekanaty. Nowy podział diecezji włocławskiej na dekanaty przeprowadził biskup włocławski Andrzej Wołłowicz. Mimo presji zaborczej biskup włocławski tworzył dekanaty w ten sposób, aby dziekani mogli spełniać w nich należycie swoje obowiazzi dziekańskie. Z dekanatu częstochowskiego zostały wyłączone dwie parafie - Krzepice i Przystajń i włączone do nowego dekanatu krzepickiego. Natomiast z dawnych dekanatów brzezińskiego i radomszczańskiego $\mathrm{w}$ archidiecezji gnieźnieńskiej do dekanatu częstochowskiego $\mathrm{w}$ diecezji włocławskiej zostały przyłączone następujące parafie: Borowno, Kłomnice, Kruszyna, Mstów, Mykanów, Poczesna, Przyrów, Truskolasy, Wilkowiecko i Żuraw oraz filie w Konopiskach i Rędzinach. Na terenie Częstochowy istniały nadal wszystkie klasztory paulińskie ${ }^{6}$.

${ }^{5}$ J. Z w i ąz e k, Dziatalność oświatowa ks. Michała Zagalskiego w dekanacie częstochowskim w latach 1810-1825. ,Summarium. Sprawozdania Towarzystwa Naukowego KUL” R. 4:1975, s. 177-189; J. Z w i ą z e k, Jasna Góra w dziele szerzenia oświaty wśród ludu. „Chrześcijanin w Świecie" R. 14:1982 nr 4-5 (106-107), s. 53-69.

${ }^{6}$ Elenchus universi cleri dioecesis Vladislaviensis seu Calissiensis, Versoviae 1822 14, s. D 13-14. 
W XVIII i XIX wieku wydarzyły się ważne fakty w dziejach Częstochowy. W 1717 r. wieś Częstochowa (Częstochówka) otrzymała prawa miejskie, będąc miastem należącym do klasztoru paulińskiego. W tym samym roku $8 \mathrm{IX} 1717 \mathrm{r}$. odbyła się koronacja Cudownego Obrazu Matki Boskiej Częstochowskiej na Jasnej Górze koronami papieskimi. Wreszcie 19 VIII 1826 r. dotychczasowe dwa miasta Stara Częstochowa (nad Warta) i Nowa Częstochowa (paulińskie) zostały przyłączone w jeden organizm miejski pod nazwą Częstochowa. Został wówczas wyznaczony główny szlak prowadzący od kościoła św. Zygmunta na Jasną Górę. Odtąd następował stały rozwój miasta, a to powodowało wzrost liczby jego mieszkańców ${ }^{7}$. Te czynniki spowodowały jednak zmiany w strukturze parafialnej. Parafia liczyła ok. $400 \mathrm{~km}^{2}$ powierzchni i ok. 6000 wiernych, ale jej podział był niemożliwy ze względu n zakazy wydane przez cara Aleksandra II w $1817 \mathrm{r}^{8}$.

Obraz parafii częstochowskiej został przedstawiony szczegółowo podczas spisu tabelarycznego z dnia 30 XI 1857 r. Podano w nim wykaz miejscowości należących do parafii, liczbę mieszkańców w każdej miejscowości i odległości od kościoła parafialnego ( $\mathrm{w}$ wiorstach - wiorsta liczyła 1066,78 m.).

Wykaz miejscowości i liczby wiernych w parafii częstochowskiej w $1857 \mathrm{r}$.

\begin{tabular}{|c|l|r|r|}
\hline Lp. & \multicolumn{1}{|c|}{ Nazwa miejscowosci } & Liczba wiernych & Odległość \\
\hline 1 & Częstochowa miasto & 6085 & \\
\hline 2 & Błeszno wiés & 464 & 4 wiorst \\
\hline 3 & Ostatni Grosz & 44 & 2 \\
\hline 4 & Bór & 57 & 2 \\
\hline 5 & Brzeziny & 104 & 7 \\
\hline 6 & Dabie & 27 & 2 \\
\hline 7 & Brzeziny II & 222 & 9 \\
\hline 8 & Poczekaj & 12 & 2,5 \\
\hline 9 & Stara Huta i Sobaczyna & 78 & $9-10$ \\
\hline 10 & Nowa Wieś i Słowik & 155 & 10 \\
\hline 11 & Wrzosowa & 272 & 7 \\
\hline 12 & Stradom i zacisze & 506 & 2 \\
\hline 13 & Wyczerpy i Wyczerpy Szlach. & 120 & 5 \\
\hline 14 & Kamień & 12 & 3 \\
\hline 15 & Dźbów & 571 & 7 \\
\hline 16 & Wierzchowiska & 135 & 10 \\
\hline 17 & Lojki & 151 & 7 \\
\hline 18 & Lisiniec i Kawodrza & 982 & 4 \\
\hline 19 & Gnaszyn, Baribór, Grabówka & 206 & $4-6,5$ \\
\hline
\end{tabular}

${ }^{7}$ F. S o b a ls k i, Częstochowa w latach 1826-1905. W: Dzieje Częstochowy od zarania, s. 825 .

${ }^{8}$ D. O 1 s ze w s k i, Duszpasterstwo a przemiany społeczno-religijne w Zagłębiu Dąbrowskim $w X I X w$. „Ślaskie Studia Historyczno-Teologiczne” t. 8:1975, s. 133; B. K u m o r, Ustrój i organizacja Kościota w okresie niewoli narodowej 1772-1918, Krakow 1980, s. 686-687. 


\begin{tabular}{|r|l|r|r|}
\hline 20 & Wielki Bór, Pleszyny & 139 & 5 \\
\hline 21 & Wola Hankowska & 76 & 14 \\
\hline 22 & Kiedrzyn & 216 & 5 \\
\hline 23 & Kuźnica Marianowa & 118 & 6 \\
\hline \multicolumn{2}{r|}{ Razem } & 10752 & \\
\hline
\end{tabular}

Źródło: Spis tabelaryczny majątku duchownego należącego do kościoła i probostwa parafii miasta Częstochowy, - Archiwum Diecezjalne w Częstochowie, sygn. II 31, s. 2.

W takim stanie parafia i dekanat częstochowski istniały do czasów Powstania Styczniowego. W wyniku represji popowstaniowych został zlikwidowany klasztor pauliński przy kościele św. Zygmunta oraz klasztor przy kościele św. Barbary (podobnie i filialista w Knopiskach). Jednocześnie duszpasterze paulińscy w parafii częstochowskiej musieli zaprzestać działalności parafialnej. Od tego czasu duszpasterstwo parafialne przejęli duchowni diecezjalni. Pierwszym proboszczem został ks. kanonik Józef Rzewuski. Parafia częstochowska należała wówczas do I kategorii placówek duszpasterskich.

Wkrótce została przeprowadzona także reorganizacja dekanatów. Według zamierzeń władz carskich granice dekanatu miały przeto być dostosowane do granic powiatów. Dekanat częstochowski miał przeto dostosowany do granic powiatu częstochowskiego w guberni piotrkowskiej. W skład powiatowego dekanatu częstochowskiego weszły następujące parafie: Biała, Częstochowa, Danków, Kamienica Polska, Kłobuck, Konopiska, Krzepice, Miedzno, Mstów, Mykanów, Parzymiechy, Poszesna, Przyrów, Przystajń, Rędziny, Starokrzepice, Trusoklasy, Wąsosz, Wilkowiecko i Żuraw - łącznie 20 parafii'.

Dodać należy, że w latach 1870-1872 w Częstochowie została wybudowana na miejscu dawnej katolickiej kaplicy pod wezwaniem św. Jakuba cerkiew prawosławna pod wezwaniem śś. Kiryła i Metoda dla wyznawców prawosławia $\mathrm{z}$ całego powiatu częstochowskiego ${ }^{10}$.

Miasto Częstochowa w II połowie XIX wieku przeżywało okres wielkiego rozwoju gospodarczego. Dzięki przeprowadzeniu przez miasto kolei warszawskowiedeńskiej oraz dogodnym warunkom hydrograficznym w mieście zaczął rozwijać się w szybkim tempie przemysł metalurgiczny i włókienniczy oraz różne dziedziny rzemiosła ${ }^{11}$. Wraz ze wzrostem liczby mieszkańców powstawał problem tworzenia nowych parafii. Dotyczyło to zwłaszcza zachodniej części miasta. Biskup włocławski Aleksander Bereśniewiecz chciał rozwiązać problem duszpasterstwa parafialnego poprzez powiększenie liczby wikariuszy w dotychczasowej parafii. Mieszkańcy zachodniej części parafii zabiegali jednak o to, ażeby w tej części utworzyć nową parafię. Władze carskie nie zezwalały na tworzenie no-

${ }^{9}$ Catalogus ecclesiarum et utriusque cleri tam saecularis quam regularis Vladislaviensis seu Calissiensis pro anno Domini 1879, Warszawa 1878, s. 53-82.

${ }^{10}$ Dzieje kościoła św. Jakuba w Częstochowie, Częstochowa 1937, s. 8-9.

${ }^{11}$ B. P u c z y ń s k i, Rozwoój gospodarczo-spoteczny Częstochowy w okresie II Rzeczpospolitej. W: Dzieje Częstochowy od zarania, s. 170-171; H. Rola: Częstochowa w latach 1905-1918. W: Dzieje Częstochowy od zarania, s. 112. 
wych parafii. Ale przed Jasną Górą władze carskie w 1889 r. wybudowały ogromny pomnik cara Aleksandra II. Wobec wrogich nastrojów miejscowej ludności władze rosyjskie zezwoliły na utworzenie parafii przy popaulińskiej świątyni św. Barbary. Parafia została utworzona w $1891 \mathrm{r}^{12}$ Wcześniej, bo w $1866 \mathrm{r}$. powstała parafia w Konopiskach, a w 1910 r. została wydzielona z parafii św. Zygmunta nowa parafia na Rakowie pod wezwaniem Opieki św. Józefa. Natomiast w czasie I wojny światowej została utworzona parafia pod wezwaniem św. Rodziny, także wydzielona z parafii św. Zygmunta.

W zmienionych warunkach politycznych w dniu 1 I 1917 r. biskup włocławski Stanisław Zdzitowiecki przeprowadził nowy podział diecezji na dekanaty. Dotychczasowy dekanat częstochowski został podzielony na 3 nowe dekanaty częstochowski w nowych granicach, kłobucki i mstowski. W nowym dekanacie częstochowskim znalazły się następujące parafie: w Częstochowie - parafia św. Zygmunta i św. Barbary oraz Biała, Blachownia, Kamienica Polska, Konopiska, Poczesna, Raków i Starcza, a wkrótce miała powstać parafia św. Rodziny w Częstochowie $^{13}$. Częstochowskie parafie należały do I kategorii, a parafie będące poza miastem należały do III kategorii placówek parafialnych ${ }^{14}$.

Stały wzrost liczby mieszkańców w Częstochowie i znaczenia tego miasta spowodował, że biskup włocławski Stanisław Zdzitowiecki w dniu 20 XI 1918 r. ustanowił w Częstochowie wikariat generalny i oficjalat terenowy dla południowej części diecezji włocławskiej. Wikariuszem generalnym i oficjałem został mianowany biskup pomocniczy Władysław Krynicki. W ten sposób powstał w Częstochowie kościelny trybunał sądowy, w którym pracowało kilku duchownych, specjalistów $\mathrm{z}$ prawa kościelnego ${ }^{15}$.

\section{CZESTOCHOWA STOLICA DIECEZJI}

W okresie niewoli narodowej, a także w pierwszych latach niepodległej Polski ogromnie wzrosło znaczenie sanktuarium maryjnego na Jasnej Górze. Przybywali tutaj nie tylko liczni pielgrzymi, ale Jasna Góra stała się miejscem ogólnopolskich nabożeństw o charakterze religijno-patryiotycznym. Polscy biskupi po zakończeniu I wojny światowej byli przekonani, że w nowym podziale Kościoła w Polsce na metropolie i diecezje powinna być utworzona nowa diecezja ze stolicą w Częstochowie. Takie postulaty przede wszystkim przedkładał konferencji polskich biskupów ordynariusz włocławski Stanisław Zdzitowiecki. Faktycznie

${ }^{12}$ Archiwum Parafialne św. Barbary w Częstochowie. Kronika parafii św. Barbary w Częstochowie, s. 20-23.

${ }^{13}$ S. Zdzitowiecki, Nowy podziat dekanatów. „Kronika Diecezji Kujawsko-Kaliskiej" R. 11:1917, s. 4.

${ }^{14}$ Catolagus ecclesiarum et utriusque cleri tam saecularis quam regularis dioecesis Vladislaviensis seu Calissiensis pro anno Domini 1920, Wladislaviae 1919, s. 117-118.

${ }_{15}$ Trybunat pomocniczy w Częstochowie. „Kronika Diecezji Kujawsko-Kaliskiej” R. $12: 1918$, s. 334. 
na mocy bulli pap. Piusa XI „Vixdum Poloniae unitas” z dnia 28 października 1925 r. została utworzona diecezja częstocinowska w metropolii krakowskiej. Stolicą diecezji została Częstochowa. Pierwszym biskupem w nowopowstałej diecezji został ks. dr Teodor Kubina. Diecezja została utworzona z południowej części diecezji włocławskiej i południowo-zachodniej części diecezji kieleckiej (Zagłębie Dąbrowskie). Nowa diecezja liczyła wówczas 15 dekanatów, 174 parafie, 257 kapłanów i 877.037 wiernych $^{16}$. W „Pierwszym liście pasterskim” z dnia 25 III 1926 r. biskup Kubina pisal: „I diecezja jest dziełem apostolskim, a tym samym dziełem Chrystusa Pana, przez którego upoważnieni apostołowie organizowali Kościół Boży. Zatem i diecezja częstochowska i biskup częstochowski są dziełem Bożym.... Przechodziły wieki i przekazywał owe słowa od pokolenia do pokolenia i przygotowywały warunki dla ich spełnienia w Częstochowie. Ale dopiero w naszych czasach, gdy Polska zmartwychwstała, słowa te stały się jakby ciałem, stały się radosną rzeczywistością" ${ }^{317}$. A dalej w tymże liście stwierdzał: „Stało się to dla Częstochowy, tej ziemi świętej, tego serca religijnego Polski, tej niezachwianej twierdzy wiary i ducha. Otwierając źródło apostolskie u stóp Jasnej Góry, podnosząc Częstochowę do godności stolicy biskupiej, tworząc z ziem otaczających ją diecezję Ojciec św. i biskupi chcieli tej Częstochowie dodać nowego blasku, przysporzyć jej nowych wiecznych sił, aby w nowej Polsce jeszcze skuteczniej mogła spełniać swoją dziejową misję jako strażnica wiary i ducha wśród narodu" "18 .

Z chwilą utworzenia diecezji częstochowskiej kościół parafialny pod wezwaniem św. Rodziny stał się kościołem katedralnym, ecclesia matrix dla wszystkich kościołów w diecezji. Katedra stała się miejscem odprawiania pontyfikalnych nabożeństw przez biskupa. Jednocześnie powstały w diecezji instytucje diecezjalne - Kuria Biskupia i Sąd Biskupi oraz Dom Księży Emerytów. Tu powstała także redakcja tygodnika diecezjalnego „Niedziela" i innych czasopism diecezjalnych. W późniejszych latach powstały tutaj i działały zarządy centralne stowarzyszeń kościelnych z Diecezjalnym Instytutem Akcji Katolickiej na czele. Jedynie seminarium duchowne zostało otwarte w Krakowie. Wreszcie w Częstochowie odbywały się zebrania dziekanów i konsultorów diecezjalnych. To wszystko było powodem, że w stolicy diecezji mieszkało wielu kapłanów, a także do instytucji diecezjalnych przybywali kapłani z całej diecezji. W okresie okupacji hitlerowskiej Częstochowa znalazła się w granicach Generalnej Guberni. Nadal działały instytucje diecezjalne, a biskup mieszkał w Częstochowie. Także w okresie totalitaryzmu komunistycznego Częstochowa była stolicą diecezji częstochowskiej.

${ }^{16}$ B. K u m or, Granice metropolii i diecezji polskich. „Archiwa, Biblioteki i Muzea Kościelne" t. 20:1970, s. 354-358; J. Z w i ą z e k: Dzieje diecezji częstochowskiej w okresie II Rzeczpospolitej, Częstochowa 1990, s. 30-41.

${ }^{17}$ T. K u b i n a, Pierwszy list pasterski. W: W podniostych chwilach i doniostych sprawach, wyd. W. Koźlicki, Częstochowa 1931, t. 1 s. 6.

${ }^{18}$ Tamże, t. 1 , s. 8. 


\section{ROZWÓJ SIECI PARAFIALNEJ I DEKANALNEJ W CZESTOCHOWIE}

W chwili erygowania diecezji częstochowskiej w tym mieście były 4 parafie: św. Zygmunta, św. Rodziny, św. Barbary i św. Rocha. Z upływem lat w diecezji, a także w Częstochowie powstawały nowe parafie i dekanaty.

W poczatkowych latach istnienia diecezji istniała pilna potrzeba przeprowadzenia reorganizacji sieci parafialnej. Wiele parafii liczyło zbyt wielu parafian, a inne znów były bardzo rozległe pod względem terytorialnym. Biskup Kubina widział tę konieczność, ale w tych latach $w$ diecezji było zbyt mało kapłanów, aby podejmować działania w tym kierunku. Dopiero w 1938 r. biskup Kubina wydał list pasterski o parafiach i życiu parafialnym, który miał być podstawa tworzenia nowych parafii. Jednakże wybuch II wojny światowej zahamował tę działalnośćc ${ }^{19}$. W okresie działalności biskupa Kubiny (1925-1951) powstały w Częstochowie następujące parafie: św. Józefa na Rakowie (osada Raków została włączona do Częstochowy), św. Antoniego, św. Jakuba, Najśw. Serca Jezusowego, Opatrzności Bożej, św. Andrzeja Boboli w Kiedrzynie i śś. Apostołów Piotra i Pawła na Lisińcu ${ }^{20}$.

Potrzebę zmodernizowania sieci parafialnej widział również drugi biskup częstochowski Zdzisław Goliński (1951-1963). W ciaggu kilku początkowych lat jego działalności w diecezji tworzenie nowych parafii było prawie niemożliwe. Władze administracyjne nie zezwalały na organizowanie nowych parafii. Dopiero po październiku $1956 \mathrm{r}$. zaistniały dogodniejsze warunki pod tym względem. Biskup Goliński wówczas faktycznie utworzył wiele nowych parafii przekształcając wtedy wiele ekspozytur, powstałych za czasów biskupa Kubiny w pełnoprawne parafie oraz tworząc nowe parafie. W Częstochowie powstały wtedy 4 parafie: Miłosierdzia Bożego, św. Stanisława Kostki, św. Judy Tadeusza i Matki Boskiej Zwycięskiej ${ }^{21}$.

Ograniczenia w dziele erygowania nowych parafii nie ustały także w okresie działalności biskupa Stefana Bareły (1964-1984). Mimo zakazu takiej działalności biskup tworzył nowe placówki duszpasterskie w formie wikariatów terenowych, ekspozytur czy filii. W Częstochowie zostały erygowane w tych latach następujące parafie: Najśw. Maryi Panny Wspomożenia Wiernych, św. Stanisława Biskupa, Wniebowstapienia Pańskiego, św. Franciszka z Asyżu, NMP Królowej Polski, św. Rocha (rektorat), św. Jacka, bł. Jadwigi Królowej, św. Kazimierza i św. Wojciecha ${ }^{22}$.

Najwięcej parafii w Częstochowie erygował biskup Stanisław Nowak (od 1984 r.). Zmieniły się warunki polityczne. Władze państwowe nie ingerowały

${ }^{19}$ T. K u b i n a, List pasterski o parafiach $i$ życiu parafialnym. "Wiadomości Diecezjalne" R. 13:1938, s. 37-45.

${ }^{20} \mathrm{~J} . \mathrm{Z}$ w i ą z e k, Rozwój sieci parafialnej $w$ diecezji częstochowskiej w latach 1925-1963: „Częstochowskie Studia Teologiczne” t. 1:1973, s. 243-250, 255-257.

${ }^{21}$ Tamże, s. 251-253, 257-259.

${ }^{22}$ Archidiecezja Częstochowska. Katalog 1993, pod red. J. Mielczarka i M. Mikolajczyka, Częstochowa 1993, s. 88-160. 
w wewnętrzną działalność kościelną w tym stopniu jak to miało miejsce w wcześniejszymi okresie. W okresie działalności biskupa Stanisława Nowaka powstały w stolicy diecezji następujące parafie: św. Elżbiety Węgierskiej, św. Floriana, św. Jadwigi Śląskiej, św. Jana Chrzciciela, św. Rafała Kalinowskiego, bł. Urszuli Ledóchowskiej, Nawrócenia św. Pawła Apostoła, Niepokalanego Poczęcia NMP, śś. Męczenników Benedykta, Jana, Mateusza, Izaaka i Krystyna, św. Jana Kantego, św. Maksymiliana Kolbe, NMP z Góry Karmel, Nawiedzenia NMP, śś. Swierada i Benedykta, Imienia Maryi (rektorat), Najśw. Ciała i Krwi Chrystusa, NMP Królowej Anielskiej, Matki Boskiej Częstochowskiej, św. Jana Sarkandra, św. Alberta Chmielowskiego, św. Kaspra del Bufalo i św. Melchiora Grodzickiego ${ }^{23}$.

W latach istnienia diecezji częstochowskiej dzięki zwiększającej się liczbie parafii w Częstochowie następowały także zmiany w dekanacie częstochowskim. W chwili powstawania diecezji dekanat częstochowski obejmował następujące parafie: w Częstochowie - św. Barbary, św. Józefa (Raków), św. Rocha, św. Rodziny i św. Zygmunta oraz Blachownię, Białą, Kalej, Kamienicę Polską, Konopiska, Poczesną i Starczę. W latach 1926-1928 zostały włączone do dekanatu parafie Olsztyn i Truskolasy, a w latach 1936-1937 zostały utworzone parafie św. Antoniego Padewskiego i św. Jakuba oraz ekspozytury Dźbów, Gnaszyn i Wrzosowa. W dniu 14 stycznia 1939 r. dotychczasowy dekanat częstochowski biskup Kubina podzielił na dwa dekanaty: częstochowski miejski (parafie w mieścic św. Antoniego, św. Barbary, św. Jakuba, św. Józefa, św. Rocha, św. Rodziny i św. Zygmunta) i dekanat podmiejski (parafie i ekspozytury wiejskie - Biała, Blachownia, Dźbów, Gnaszyn, Kalej, Kamieenica Polska, Konopiska, Olsztyn, Poczesna, Starcza, Truskolasy i Wrzosowa). W okresie okupacji hitlerowskiej w granicach dekanatu częstochowskiego miejskiego biskup Kubina utworzył 4 nowe placówki duszpasterskie (św. Andrzeja Boboli, Opatrzności Bożej, śś. Apostołów Piotra i Pawła oraz Najśw. Serca Pana Jezusa). Podczas reorganizacji sieci parafialnej i dekanalnej $\mathrm{w}$ diecezji przeprowadzonej w dniu 30 I $1946 \mathrm{r}$. biskup Kubina jedynie zmienił nazwy dekanatów częstochowskich. Dotychczasowy dekanat częstochowski miejski otrzymał nazwę dekanat częstochowski, a dekanat częstochowski podmiejski otrzymał nazwę dekanat blachowieński ${ }^{24}$.

W latach działalności biskupa Zdzisława Golińskiego powstało w Częstochowie, jak to wyżej podano, kilka nowych parafii i to było powodem podziału, w dniu 31 XII 1957 r., dotychczasowego dekanatu częstochowskiego na dwa dekanaty: częstochowski I (św. Barbary, św. Jakuba, św. Krzyża, Matki Boskiej Zwycięskiej, Miłosierdzia Bożego, śś. Piotra i Pawła, św. Stanisława Kostki i św. Andrzeja Boboli) i częstochowski II (św. Antoniego, św. Józefa, św. Judy Tadeusza, Níepokalanego Serca Maryi, Najśw. Serca Pana Jezusa, Opatrzności Bożej, św. Rodziny - katedralna i św. Zygmunta ${ }^{25}$.

${ }^{23}$ Dane podano na podstawie dekretów ogłaszanych w "Częstochowskich Wiadomościach Diecezjalnych" i „,Wiadomości Archidiecezji Częstochowskiej” z 1. 1985-1999.

24 J. Z w i ą z e k, Rozwój sieci dekanalnej w diecezji częstochowskiej w latach 1925-1970. „Częstochowskie Wiadomości Diecezjalne" R. 46:1972, nr 4-6 s. 161-167.

${ }^{25}$ Tamże, s. 167-169. 
Analogiczna sytuacja wystapiła w okresie działalności biskupa Stefana Bareły. Powstały nowe placówki duszpasterskie głównie w dekanacie częstochowskim I, który liczył 13 parafii. Dlatego dekretem z dnia 16 II 1975 r. dekanat częstochowski I został podzielony na dwa nowe dekanaty: częstochowski I w nowych granicach (parafie: św. Andrzeja Boboli, sw. Jakuba, Opatrzności Bożej, św. Stanisława Kostki i św. Zygmunta) i częstochowski III (parafie: św. Barbary, św. Krzyża, MB Zwycięskiej, Miłosierdzia Bożego i śś. Piotra i Pawła) ${ }^{26}$. Istniał także dekanat częstochowski II. Nowy podział dekanalny wprowadził tenże biskup dekretem z dnia 25 XI 1983 r. Parafie częstochowskie zostały podzielone na 4 dekanaty: św. Rodziny w Częstochowie, Matki Boskiej Jasnogórskiej w Częstochowie, św. Wojciecha w Częstochowie i św. Zygmunta w Częstochowie ${ }^{2}$. Wreszcie biskup Stanisław Nowak dekretem z dnia 26 XI 1998 r. utworzył w północno-zachodniej części miasta dekanat Podwyższenia Krzyża świętego (Świętokrzyski) w Częstochowie ${ }^{28}$.

\section{CZESTOCHOWA STOLICA METROPOLII}

Najważniejszym wydarzeniem w kościelnych dziejach Częstochowy była decyzja pap. Jana Pawła II zawarta w bulli „Totus Tuus Poloniae populus” z dnia 25 III 1992 r., podnosząca Częstochowę do godności stolicy metropolii Częstochowskiej. Jednocześnie dotychczasowa diecezja częstochowska została podniesiona do godności archidiecezji. Bulla papieska głosiła: „Noviter statuta Provincia Częstochoviensis constabit ex sede metropolitana Częstochoviensi, nec-non suffraganeis noviter constitutis dioecesibus Sosnoviensi et Radomiensi"29.

W tym samym dniu pap. Jan Paweł II specjalna bulla mianował dotychczasowego biskupa częstochowskiego Stanisława Nowaka arcybiskupem metropolita częstochowskim. Papież stwierdzał: „Cum sit eligendus sacrorum Antistites metropolitanae Sedis Częstochoviensis, hoc ipso die e dioecesi eodem nomine effectae, tu, Venerabilis Frater, qui hucusque scite ac naviter functus es munere Episcopi illius Ecclesiae, omnino Nobis videris idoneus ad huiusmodi gerendum officium. De plenitudine igitur Apostolicae Nostrae potestatis te constituimus Archiepiscopum Metropolitam Częstochoviensem, iuribus additis et privilegiis quibus potiuntur alii per orbem metropolitae et cum oneribus atque officiis quibus illi itidem subvenient" ${ }^{\text {30 }}$.

${ }^{26} \mathrm{~S}$. B a r e $\nmid$ a, Dekret o reorganizacji sieci dekanalnej. „Częstochowskie Wiadomości Diecezjalne" R. 49:1975, s. 202-203.

${ }^{27} \mathrm{~S}$. B a r eła, Dekret reorganizujacy sieć dekanalnq $w$ biskupim mieście Częstochowie. „Częstochowskie Wiadomości Diecezjalne" R. 58:1984, s. 12-13.

${ }^{28}$ S. N o w a k, Dekret ustanawiający dekanat Podwyższenia Krzyża Síwiętego (Świętokrzyski) w Częstochowie. Okólnik z grudnia 1998 r., s. 1.

${ }^{29} \mathrm{~J}$ a n P a weł I I, Totus Tuus Poloniae populus. „Wiadomości Archidiecezji Częstochowskiej" R. 66:1992, s. 82.

${ }^{30} \mathrm{~J}$ a n P aw e 1 I I, Bulla podnoszq̨ca biskupa częstochowskiego dra Stanistawa Nowaka do godności arcybiskupa metropolity częstochowskiego. „Wiadomości Archidiecezji Czẹstochowskiej" R. 66:1992, s. 88. 
Kościelna przeszłość Częstochowy rozpoczęła się od wsi przynależnej do średniowiecznej parafii we Mstowie. W późniejszych latach powstała parafia częstochowska ze świątynia pod wezwaniem Wniebowzięcia Matki Boskiej na Starej Górze. Wraz z rozwojem Częstochowy do parafii zostały przyłączone okoliczne miejscowości. Z czasem parafia częstochowska pod wezwaniem św. Zygmunta stała się największą w okolicy. Pod koniec XVIII wieku został utworzony dekanat częstochowski. W okresie II Rzeczypospolitej powstała na mocy bulli pap. Piusa XI „Vixdum Poloniae unitas” nowa diecezja częstochowska ze stolicą diecezji w Częstochowie. W ciagu 75 lat istnienia diecezji powstawały w Częstochowie nowe parafie i nowe dekanaty. Erygowanie nowych placówek duszpasterskich w mieście było odpowiedzią na wielki rozwój ludnościowy Częstochowy. W 1999 r. w Częstochowie było prawie 50 parafii i 5 dekanatów.

Na mocy bulli pap. Jana Pawła II „Totus Tuus Poloniae populus” z dnia 25 III 1992 r. została utworzona metropolia częstochowska, której sufraganiami zostały diecezje sosnowiecka i radomska. Jednocześnie diecezja częstochowska została podniesiona do godności archidiecezji. Dotychczasowy biskup częstochowski dr Stanisław Nowak otrzymał godność arcybiskupa metropolity częstochowskiego. Częstochowa została podniesiona do godności stolicy metropolii. 